\title{
Body image perception in Mexican university athletes VS non-athletes
}

\author{
Jesús Enrique Peinado Pérez ${ }^{1}$, Judith Margarita Rodríguez-Villalobos ${ }^{1}$, \\ Juan Francisco Aguirre Chávez ${ }^{1, *}$, José Leandro Tristán Rodríguez ${ }^{2}$, Isabel Castillo Fernández ${ }^{3}$ \\ ${ }^{1}$ Faculty of Physical Culture Sciences, Autonomous University of Chihuahua, México \\ ${ }^{2}$ Faculty of Sport Organization, Autonomous University of Nuevo León, México \\ ${ }^{3}$ Faculty of Psychology, University of Valencia, Spain
}

\section{Email address:}

jaguirre@uach.mx (J. F. A. Chávez)

\section{To cite this article:}

Jesús Enrique Peinado Pérez, Judith Margarita Rodríguez-Villalobos, Juan Francisco Aguirre Chávez, José Leandro Tristán Rodríguez, Isabel Castillo Fernández. Body Image Perception in Mexican University Athletes VS Non-Athletes. Science Journal of Public Health. Vol. 2, No. 4, 2014, pp. 257-260. doi: 10.11648/j.sjph.20140204.12

\begin{abstract}
The objective of this study consisted in determining the differences and similarities among Mexican University students who practice a sport on a regular basis with those who do not do, concerning their body image perception to their actual, ideal, social and body size dissatisfaction. A total sample of 304 male University students, aged 18-29 years participated in this study; 146 of them practice a sport and participate regularly in a tournament or competition. A quantitative approach with a descriptive and transversal survey design was used. All the participants completed the Contour Drawing Rating Scale adapted and computerized by [1]. The results of the one-way multivariate analysis of variance, followed by the one-way univariate analyses of variance, show that university students who don't participate in a regular sport are the ones who show thicker models for their present, ideal and social figure, in addition to demonstrating higher body size dissatisfaction. Further research should reply these findings in larger samples.
\end{abstract}

Keywords: Body Image, Physical Activity, Body Size Dissatisfaction, Figure Rating Scale

\section{Introduction}

In recent years modern societies have given an excessive value to body image, many of which have created a subculture based on body size perception and the importance of the ideal body image [2] The ideal "thin" person and the concerns about weight come from a cultural ideal although nowadays it is considered aesthetic, this is, only a passing fashion and not necessarily healthy nor accessible which could have negative consequences as great concern about weight and body image that can be expressed as body size dissatisfaction, seen as the extent in which individuals value or despise their bodies in distortion to body image, that is the lack of accuracy in body size determination [3].

On the other hand, the relation between body image and physical exercise enables to show that participation in physical exercise is related with a positive body image [4-6]. It has been found that people who are more active show a more positive attitude toward their own body than sedentary people $[7,8]$; that sport and physical activity are means to improve subjects' health and to prevent obesity [9-11] and that these practices have a positive effect on the physical image and the pleasure related to its acquisition [12]. Therefore it has been proposed that the practice of physical exercise should be exploited also as mean to protect health, and the field to explore corporal pleasure, fun and enjoyment [12].

In the second group are those studies pointing to a potentially negative exercise effect about body image, based on the existing relation among the influence of practice and sport performance, the subject's body image perception and the possibility of suffering an eating disorder. Some studies have found that among risk factors for eating disorder development in top athletes there is a socio-cultural influence of sliminess, anxiety of sport performance and self-evaluation of sport failure and success; in a way, that if these factors lead to an excessive concern about the size and the form of the body, there is a higher possibility of an eating disorder to appear [13,14].

In this sense, it is of special relevance to find out if practicing regular physical activity produces or not physical or cognitive benefits which contribute to diminish the concern about physical image while improving body image perception. 
This study tends to determine the differences and similarities among Mexican University students who practice a sport a regular basis with those who do not do, regarding their current body image perception to their actual, ideal, social and body size dissatisfaction.

\section{Methods}

\subsection{Participants}

A sample of 304 male University students, aged 18-29 years $(M=19.76 ; S D=2.76)$ participated in the present study; 146 of them practice a sport and participate regularly in a tournament or competition. A convenience sampling was used in order to try covering the representative of different school levels studied.

\subsection{Instrument}

Scale for the estimation of body shape, adapted and computerized by [1], of the original version "Contour Drawing Rating Scale" (CDRS) of [15]. The CDRS consists of nine drawings of a female figure (for female participants) or a male figure (for male participants). Each drawing increases in size from extremely thin (1) to very obese (9). Participants are asked to rate their current, ideal and social body shape. The discrepancy between the ideal and current size scores is an index of body size dissatisfaction.

\subsection{Design}

Regarding the design of the study, a quantitative approach with a descriptive and transversal survey design was used [16]. The independent variable was sports practice (athletes and non-athletes) and the dependent variables were the scores on body shape (current, ideal and social) and body size dissatisfaction (ideal minus current body shape).

\subsection{Procedure}

The university students were invited to participate in the present study. These students were fully informed about all the features of the project. Then, all the students that agree to participate were asked to sign a written informed consent. After the students approvals were obtained, participants completed the above mentioned questionnaire by means of the instrument module administrator of the Scales Editor Version 2.0 [17].

Participants completed the questionnaire in the computer rooms of their schools during a session. At the beginning of the session the researchers gave a general introduction about the importance of the research and how to access the questionnaire thought the software. When the participants were into the editor, the instructions about how to fill out the questionnaire correctly appeared before the instrument. Additionally, the participants were advised to ask for help if confused concerning either the instructions or the clarity of a particular item. Completion of the entire questionnaire took approximately 10 minutes. At the end of the session their participation was welcomed. Afterward, when all the participants completed the questionnaire, the data were collected by means of the results generator module of the Scales Editor Version 2.0 [17].

\subsection{Data Analysis}

Descriptive statistics (means and standard deviations) for all the variables were calculated. Subsequently, after verifying that the data met the assumptions of parametric statistical analyses, a one-way multivariate analysis of variance (MANOVA), followed by the one-way univariate analysis of variance (ANOVA), were used to examine the differences between the athletes and non athletes on the reported body shape (current, ideal and social) and index of body size dissatisfaction scores. Moreover, the effect size was estimated using the eta-squared $\left(\eta^{2}\right)$. All statistical analyses were performed using the SPSS version 20.0 for Windows (IBM $®$ SPSS ${ }^{\circledR}$ Statistics 20). The statistical significance level was set at $p<.05$.

\section{Results}

Table 1 shows the mean values and standard deviations of the variables of body shape, as well as the results of the MANOVA and the follow-up univariate ANOVAs. The MANOVA results indicated overall statistical significant differences between athletes and non athletes on the body shape scores (Wilks' $\lambda=.832 ; p<.001 ; \eta^{2}=.168$ ). Subsequently, the follow-up ANOVAs showed that compared with the athletes, the non athletes expressed a greater discrepancy between ideal and actual body shape $\left(F_{1}=\right.$ 45.745; $p<.001)$ and had higher scores of current body shape $\left(F_{1}=22.399 ; p<.001\right)$, ideal body shape $\left(F_{1}=4.633\right.$; $p=.032)$ and social body $\operatorname{shape}\left(F_{1}=22.002 ; p<.001\right)$.

\section{Discussion and Conclusions}

Results show that students who don't participate in a regular sport are those who chose thicker models for their current, ideal, social and dissatisfaction image perception besides presenting a higher body size dissatisfaction ; consisted with the reported by [18] and [19] in the sense that active students and the ones who have a better body image than sedentary students.

Table 1. Results of MANOVA for the sports practice differences on the four variables of body shape.

\begin{tabular}{llllll}
\hline & $\begin{array}{l}\text { athletes } \\
(\boldsymbol{n}=\mathbf{1 4 6})\end{array}$ & $\begin{array}{l}\text { Non-athletes } \\
(\boldsymbol{n}=\mathbf{1 5 8})\end{array}$ & $\boldsymbol{F}$ & $\boldsymbol{p}$ & $\boldsymbol{\eta}^{2}$ \\
\hline & & & 15.072 & $<.001$ & .168 \\
$\begin{array}{l}\text { current body } \\
\text { shape }\end{array}$ & $3.86(0.95)$ & $4.43(1.13)$ & 22.399 & $<.001$ & .069 \\
$\begin{array}{l}\text { ideal body shape } \\
\text { social body shape }\end{array}$ & $3.81(0.66)$ & $3.97(0.67)$ & 4.633 & .032 & .015 \\
$\begin{array}{l}\text { body size } \\
\text { dissatisfaction }\end{array}$ & $0.55(0.59)$ & $1.00(0.57)$ & 45.745 & $<.001$ & .132 \\
\hline
\end{tabular}

Note. Descriptive values are reported as mean (standard deviation). 
The results suggest that exercise should be explored as a preventive measure against the development of a negative body image or greater body dissatisfaction; Yet it is extremely important determine which characteristics (type, intensity, frequency, etc..) and mechanisms by which exercise improves body image [27].

The results obtained point out the possible benefits of practicing physical-sporting activity can generate health in adolescents. So it would important to value physical-sporting activity as a positive factor for health, and as it is reflected in this study it could enhance the positive impact toward self-body image.

\section{Acknowledgements}

This study is part of a project funded by the Secretaria de Educación Pública-Subsecretaría de Educación Superior-Dirección General de Educación Superior Universitaria de México [Mexican Ministry of Education-Department of Higher Education - General Directorate of the University Education] (OF-13-6894).

\section{References}

[1] G. Gastélum \& H. Blanco. Computerized version of the Contour Estimation Scale Figure. In Faculty of Physical Education and Sports Science (Ed.), Tenth International Conference, Faculty of Physical Education and Sports Science, 2006, pp. 285-286. México: UACH.

[2] G. Gastélum \& H. Blanco. Versión informatizada de la Escala Estimación del Contorno de la Figura. In Facultad de Educación Física y Ciencias del Deporte (Ed.), X Congreso Internacional, Facultad de Educación Física y Ciencias del Deporte, 2006, pp. 285-286. México: UACH.

[3] S. Banfield \& M. P. McCabe (2002). An evaluation of the construct of body image. Adolescence, vol. 37(146), pp. 373-393, 2002.

[4] N. Solano \& A. Cano. Anxiety in eating disorders: A comparative study. Psicothema, vol. 24(3), pp. 384-389, 2012.

[5] N. Solano \& A. Cano. Ansiedad en los trastornos alimentarios: Un estudio comparativo. Psicothema, vol. 24(3), pp. 384-389, 2012.

[6] K. A. Martin \& R. L. Bassett. Exercise and Changes in Body Image, Ginis. In T. F. Cash \& L. Smolak (Eds.), Body Image A Handbook of Science, Practice, and Prevention. New York: Guilford Press, 2012.

[7] L.A. Tucker \& R. Mortell. Comparison of the effects of walking and weight training programs on body image in middle-aged women: An experimental study. American Journal of Healt Promotion, vol. 8(1), pp. 34-42, 1993.

[8] P. A. Williams \& T. F. Cash. Effect of a circuit weight training program on the body images of collage students. Internacional Journal of Eating Disorders, vol. 30 (1), pp. 75-82, 2001.

[9] I. Tornero \& Á. Sierras. Body satisfaction and physical activity in students of the Faculty of Education Sciences of the University of Huelva. Paper presented at the Fourth
International Congress and XXV National Physical Education, Córdoba, Spain, 2008.

[10] I. Tornero \& Á. Sierras. Satisfacción corporal y actividad física en el alumnado de la facultad de ciencias de la educación de la universidad de Huelva. Paper presented at the IV Congreso Internacional y XXV Nacional de Educación física, Córdoba, España, 2008.

[11] S. Urrutia, I. Azpillaga, G. L. de Cos \& D. Muñoz. Relación entre la percepción de estado de salud con la práctica físicodeportiva y la imagen corporal en adolescentes. Cuadernos de Psicología del Deporte, vol. 20 (2), pp. 51-56, 2010 .

[12] M. J. Camacho, E. Fernández \& M. I. Rodríguez, M. I. Imagen corporal y práctica de actividad física en las chicas adolescentes: incidencia de la modalidad deportiva. Revista Internacional de Ciencias del Deporte, vol. 3(2), pp. 1-19, 2006.

[13] P. Katzmarzyk \& I. Janssen. Physical inactivity, excess adiposity and premature mortality. Obesity Reviews, vol. 4(4), pp. 257-290, 2003.

[14] P. Kokkinos. Physical Activity, Health Benefits, and Mortality Risk. ISRN Cardiology, 2012, pp. 1-14. doi: $10.5402 / 2012 / 71878$

[15] T. Alley Visual detection of body-weight change in young women. Perceptual and motor skills, vol. 73 (3), pp. 904-906, 1991.

[16] S. Márquez. Eating disorders in sport: risk factors, health consequences, treatment and prevention. Hospital nutrition, vol. 23(3), pp. 183-190, 2008.

[17] S. Márquez. Trastornos alimentarios en el deporte: factores de riesgo, consecuencias sobre la salud, tratamiento y prevención. Nutrición Hospitalaria, vol. 23(3), pp. 183-190, 2008.

[18] D. A. Williamson, R. G. Netemeyer, L. P. Jackman, D. A. Anderson, C. L. Funsch \& J. Y. Rabalais, J. Y. Structural equation modeling of risk-factors for the development of eating disorder symptoms in female atheletes. International Journal of Eating Disorders, vol. 17(4), pp. 387-393, 1995.

[19] M.A. Thompson \& J. J. Gray. Development and validation of a new body-image assessment scale. Journal of Personality Assessment, vol. 64(2), pp. 258-269, 1995.

[20] R. Hernández, C. Fernández \& P. Baptista. Research Methodology. México: McGraw- Hill, 2010.

[21] R. Hernández, C. Fernández \& P. Baptista. Metodología de la investigación. México: McGraw- Hill, 2010.

[22] H. Blanco, M. Ornelas, J. L. Tristán, A. Cocca, D. Mayorga-Vega, J. López-Walle \& J. Viciana. Editor for creating and applying computerise surveys. Procedia Social and Behavioral Sciences, 106, pp. 935-940, 2013.

[23] J. A. Moreno \& E. Cervelló. Importance of physical and sport practice and gender in the physical self from 9 to 23 years. International Journal of Clinical and Health Psychology, vol. 8(1), pp. 171-183, 2008.

[24] J. A. Moreno \& E. Cervelló. Importancia de la práctica físico-deportiva y del género en el autoconcepto físico de los 9 a los 23 años. International Journal of Clinical and Health Psychology, vol. 8(1), pp. 171-183, 2008. 
[25] G. Gastélum. Development and validation of a computerized version of body image anxiety scale and contour drawing rating scale: a study of perception and anxiety levels of body image in college of Chihuahua. Spain: University of Granada, 2011.

[26] G. Gastélum. Desarrollo y validación de una versión informatizada del body image anxiety scale y contour drawing rating scale: un estudio sobre percepción y nivel de ansiedad de la imagen corporal en universitarios chihuahuenses. España: Universidad de Granada, 2011.

[27] Martin Ginis, K. A., \& Bassett, R. L. (2012). Exercise and Changes in Body Image. In T. F. Cash \& L. Smolak (Eds.), Body Image A Handbook of Science, Practice an Prevention (pp. 378-386). New York: Guilford Press. 